\title{
Natural conservationists? Evaluating the impact of pastoralist land use practices on Tanzania's wildlife economy
}

Fred Nelson ${ }^{*}$

Correspondence: fnelson@maliasili.org Maliasili Initiatives, P.O. Box 293, Underhill VT 05489 USA

\begin{abstract}
The land management practices of pastoralist Maasai communities have a major bearing on landscapes and wildlife habitats in northern Tanzania and play a key role in maintaining habitat for one of the world's most spectacular assemblages of terrestrial large mammals. Pastoralists manage lands according to locally devised rules designed to manage and conserve key resources such as pastures and water sources. Dry season grazing reserves are an important part of traditional land management systems in many pastoralist communities, providing a 'grass bank' for livestock to consume during the long dry season when forage invariably becomes scarce and domestic animals are stressed for water and nutrients. Because of the scale and importance of northern Tanzania's wildlife-based tourism industry, and its indirect dependence on communal lands under the authority of pastoralists, these land use practices have an important economic dimension. By conserving large proportions of northern Tanzania's wildlife ecosystems, local pastoralist communities collectively make an important contribution to the national and regional economy. Using data regarding the degree to which wildlife depends on pastoralist lands in different ecosystems, and the relative importance of different areas in terms of generating revenue for the northern safari circuit, the annual value of pastoralist land uses to the wildlife-based tourism industry in northern Tanzania is estimated at approximately US $\$ 83.5$ million. The economic value of pastoralists' contribution to wildlife conservation highlights the importance of Tanzanian policies in land, livestock, tourism, and wildlife sectors prioritizing measures that promote communal rangeland management and support traditional land use practices.
\end{abstract}

Keywords: Land use, Pastoralism, Wildlife conservation, Tourism, Economic value, Ecosystem services

\section{Pastoralists, wildlife, and tourism in northern Tanzania: an overview}

Northern Tanzania's savannahs and grasslands contain some of the world's most diverse and abundant remaining terrestrial wildlife populations. This abundance of wildlife has, during the past 20 years, been the key asset underlying the development of one of Africa's fastest-growing tourism industries. By 2007, tourism was estimated to contribute $\$ 1.6$ billion directly and indirectly to Tanzania's economy, accounting for about $11 \%$ of the country's Gross Domestic Product (Mitchell et al. 2009). Northern Tanzania's tourism circuit, stretching between Mount Kilimanjaro on the east and the Serengeti to the west, 
generates more than half of Tanzania's foreign earnings from tourism, making it 'one of the most valuable strips of tourism real estate in Africa' (Mitchell et al. 2009, page 7).

In order to conserve wildlife and their habitats, and to develop sites for tourism activities, a large number of state-protected areas - national parks and game reserves - have been established in northern Tanzania's savannah landscapes during the course of the last 50 years (and in a few cases dating back to earlier colonial-era measures). These state-protected areas provide the core attractions and infrastructure of the northern tourism circuit (Figure 1).

The areas that are now designated as state-protected areas were formerly used and occupied by local communities, with parks such as Serengeti and Tarangire occupied by pastoralists prior to their gazettement. When the colonial and post-independence governments established national parks and game reserves in these customarily owned lands, local people were evicted and rights of occupancy gradually extinguished. Despite this long-running effort to divide the landscape into areas for people and areas for wildlife conservation, northern Tanzania continues to be characterized by a high level of interaction and coexistence between local resident people and wildlife. Parks and reserves are invariably situated within larger ecosystems, and wildlife continues to move across the artificial boundaries dividing communal and state lands. Many species of large mammals, such as elephants, wildebeest, and zebra, undertake annual migrations based on the seasonal availability of water, forage, and nutrients. Wildlife in northern Tanzanian ecosystems continues to rely on many lands and resources which are located outside protected areas on private and community lands, making these latter areas essential for the long-term conservation of wildlife.

The ways that local pastoralist communities manage their lands and resources thereby have a major impact on the conservation of wildlife in savannah ecosystems in northern Tanzania. Indeed, pastoralist land management practices such as grazing and the use of fire have had a major influence over the course of the past 3,000 to 4,000 years in shaping East African savannah landscapes. Many observers attribute the contemporary abundance

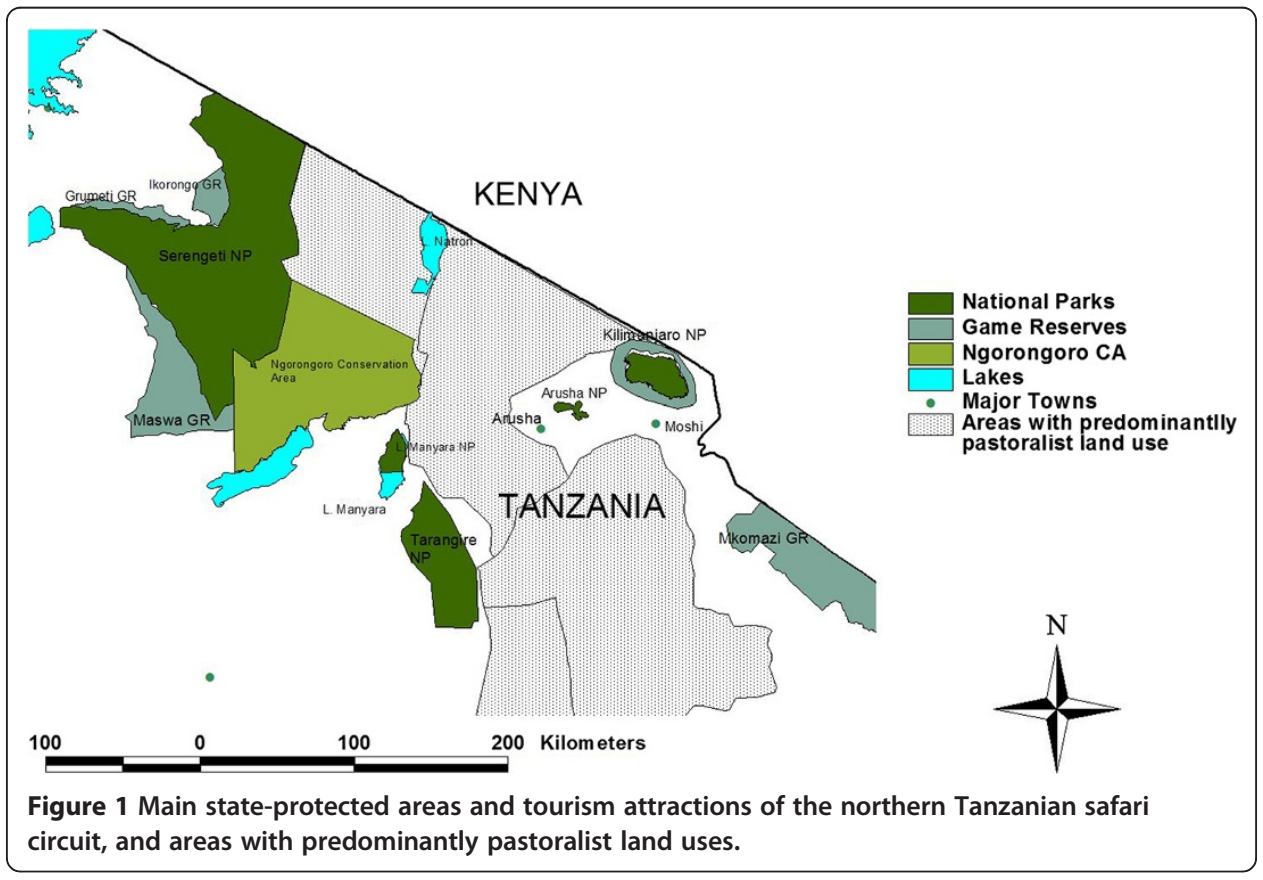


of wildlife in East Africa to the historic influences of pastoralists on savannah landscapes and on the general ecological compatibility between pastoralists and wild large mammals (Collet 1987; Western 1989; Homewood and Rodgers 1991). Pastoralists in northern Tanzania's savannah ecosystems thereby provide an economically valuable ecological service by conserving wildlife on their lands, which in turn helps to sustain the natural assets that Tanzania's growing tourism industry depends on. This article describes the nature and extent of that ecological service by pastoralists and develops a general and approximate estimate of its economic value in the context of Tanzania's wildlife-based tourism industry. Such an understanding is central to the development of economically efficient and productive national policies in sectors such as land, livestock, and wildlife in Tanzania and the harmonization of rural livelihoods with national and international conservation objectives.

\section{Sharing the land: pastoralist and wildlife interactions}

It has long been recognized that pastoralists and their livestock, and wildlife live alongside one another in East African savannah ecosystems, where they exhibit a high degree of spatial overlap or co-existence (Sitters et al. 2009; du Toit 2011). Both pastoralist livestock and wildlife utilize foraging strategies based on mobility (seasonal migrations or transhumance) in order to access pasture and water occurring in an unpredictable physical environment (Homewood and Rodgers 1991).

The degree to which pastoralists' livestock and wild ungulates compete for grazing and water resources, which in turn shapes the potential for co-existence or even symbiotic interactions, has been the subject of both research and debate within East Africa for decades. In the 1950s and 1960s, the general perception was that pastoralist overgrazing was prevalent and resulted in environmental degradation and damage to wildlife habitat. This overgrazing narrative was a central factor in the creation of the Serengeti National Park and relocation of resident people, including about 1,000 Maasai pastoralists, in 1959 (Collet 1987; Neumann 1998; see also Grzimek and Grzimek 1960). A core concept of range science at this time was the concept of carrying capacity holding that a given unit of land area can only support so many livestock (or wild animals) due to the limitations of a given volume of forage which that land area can produce (Pratt and Gwynne 1977). Pastoralists, according to this paradigm, would exceed the carrying capacity of the land by producing more livestock over time, but not selling (or eating) sufficient numbers of animals, leading to more grazing pressure on limited forage resources. Underlying this process of overgrazing was the so-called cattle complex, meaning the cultural value pastoralists place on building up large herds of livestock, and the tragedy of the commons whereby communally owned and managed pastures lacked controls limiting individuals' livestock numbers and consumption of forage, making progressive overgrazing seemingly inevitable (Lamprey 1983; see also Hardin 1968).

Many of these ideas about overgrazing, the cattle complex, and a tragedy of the commons on communal lands continue to inform policy debates over livestock, land tenure, and natural resource management in East Africa today (Mattee and Shem 2006). However, during the last 30 years, a wide range of ecological, anthropological, and institutional studies have altered thinking about rangelands and discredited or modified many earlier assumptions about pastoralist land management practices. Ecological research in semiarid areas across Africa has demonstrated the key role that rainfall plays in the condition 
of above-ground vegetation; during droughts, areas tend to lose cover but recover fairly rapidly following rainfall (Behnke et al. 1993; Dodd 1994; Scoones 1995).

\section{Pastoralists and the environment: managing uncertainty}

Pastoralists respond to these highly variable and unpredictable, non-equilibrium conditions by moving between different local pastures depending on where rain has fallen at a given time, and maintaining reciprocal relationships with neighbouring and distant communities so that livestock may seek refuge or access pastures in areas where conditions are better during times of drought (Ellis et al. 1988). A considerable body of research has emerged during the last 30 years demonstrating that pastoralist management strategies such as mobility, rotational pasture use through different wet season and dry season grazing areas, and building up cattle numbers so as to be able to endure catastrophic but relatively common periods of drought are ecologically rational measures for coping with the variable semi-arid and arid environments that these people live in (Homewood and Rodgers 1991; Behnke et al. 1993; Scoones 1995; Bourn and Blench 1999).

A major change has also occurred in thinking about the 'tragedy of the commons', both in general and specifically in relation to pastoralists. Hardin's (1968) central assumption was that such commons are effectively ungoverned by the community of resource users which utilizes such areas. By 1990s, though an array of research (e.g. Berkes 1989; Ostrom 1990) was documenting that, in fact, many commons around the world are subject to locally devised and enforced rules that govern the use of shared resources. In many instances, local rules governing resource use are as or more effective at conserving resources such as forests than the state-protected areas that formal conservation efforts often promote (Hayes 2006; Ostrom and Nagendra 2006). East African pastoralists generally manage rangelands collectively through community-level institutions (Barrow 1988; McCabe 1990; Homewood and Rodgers 1991). Maasai communities traditionally divide their collective pastures into different types of areas governed by certain traditional rules. The most fundamental division is of pastures used during the wet season and areas used as dry season refuges. Wet season pastures tend to be those without permanent water that can only be accessed during the periods of rainfall. Dry season pastures tend to be areas which have permanent water nearby or which are particularly resistant to drought, such as forests which retain vegetation that livestock can access even during severe droughts. In addition, some pastures are designated for use by calves and weak or infirm livestock. These areas, called olokeri, are close to permanent settlements and sources of water and are allocated to particular households rather than being managed at the community or village level. Figure 2 illustrates this traditional land use scheme as mapped and formalized in village by-laws in one pastoralist village in Loliondo Division, northern Tanzania (UCRT 2010).

\section{Pastoralist-wildlife interactions}

In terms of better understanding livestock-wildlife interactions in East African savannahs, a starting point is the reality that different types of animals eat different types of forage (du Toit 2011). Species such as giraffe, gerenuk, kudu, and domestic goats are browsers, eating leaves from trees and bushes, whereas species such as wildebeest, zebra, buffalo, gazelle, and cattle are grazers. Bell (1971), based on research carried out in the Serengeti, describes a process of 'grazing succession' whereby different species of 


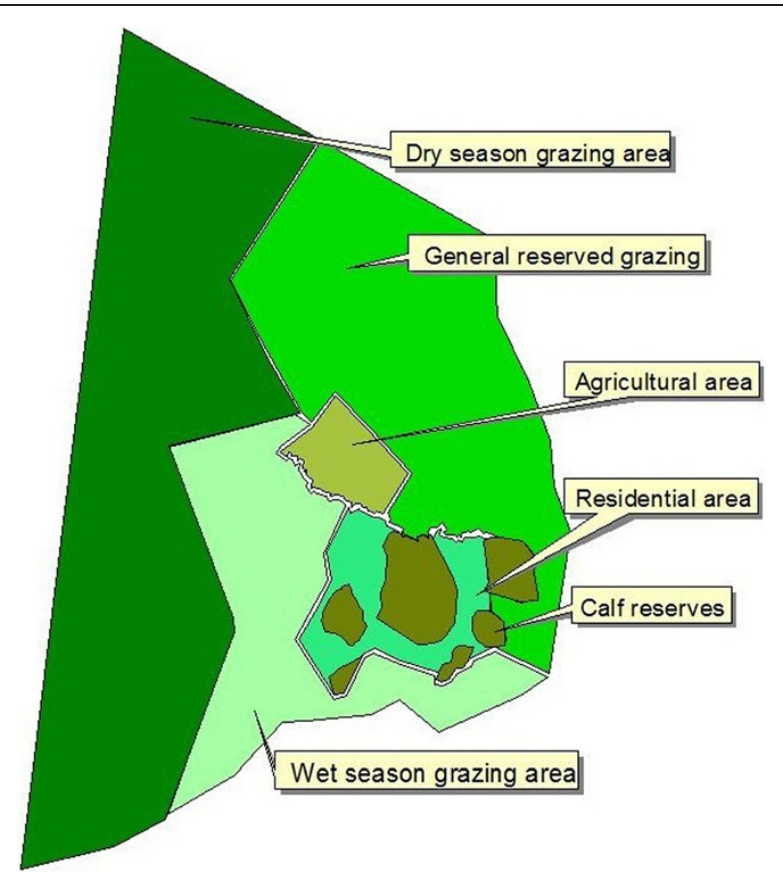

Figure 2 Land use zones for a pastoralist village in Loliondo, northern Tanzania. This is based on traditional pasture management system and formalized through land use plans and village by-laws. Adapted from UCRT (2010).

wild ungulates, such as wildebeest and zebra, progressively move through a grazing area. The diversity of grazing ungulates that exists in East Africa is possible because different species can co-exist without directly competing for grazing since their feeding preferences are different. For example, zebra eat taller, more coarse grass while wildebeest, as well as smaller grazers such as gazelle, are more selective and efficient grazers (antelopes and gazelle, unlike zebra, are ruminants and have much more efficient digestive systems) preferring shorter swards of grass. This enables wildebeest to graze areas that zebra have already passed through and grazed over initially, and in this way, zebra may facilitate grazing by wildebeest and other more selective grazers including cattle (du Toit 2011).

Interactions between livestock and wildlife may, as conditions change, be both competitive or, as in the process of grazing succession, facilitative depending on the species involved and the seasonal availability of resources. For example, Odadi et al. (2011) describe how zebra and cattle compete for forage during the dry season, when forage is more scarce, while zebra facilitate cattle access to grazing during the wet season, when grass growth is at its high point. It is important to highlight that it is not only the presence of livestock, but their absence as well, that shapes habitat conditions for wildlife in both positive and negative ways. As an example of the latter, Gichohi's (1992) study of Nairobi National Park in Kenya describes how after pastoralists were excluded from the park in the 1960s, the lower levels of cattle grazing as well as the use of fire, resulted in reduced numbers inside the park of selective grazers which prefer a low grass sward; this included hartebeest, warthog, and Thomson's gazelle. These species had benefited from the presence of livestock and pastoralist land management practices. This work illustrates what Western and Gichohi (1994) term as 'segregation effects' in savannah ecosystems, whereby human interventions that remove people from 
areas where they have had long-term influences on ecological processes and species composition can have negative cascading effects on certain wild species.

As another example of the impacts of removing pastoralists from a mixed wild and domestic grazing herbivore assemblage, in Tanzania's Ngorongoro Crater, Maasai pastoralists were evicted from living on the caldera floor in 1974 (Homewood and Rodgers 1991). Following the removal of livestock as a permanent presence in the crater (livestock are still allowed to descend into the crater to access mineral licks), different species of ungulates showed both increasing and decreasing trends over the course of the following 20 years (Table 1). Overall, wildlife biomass was unchanged after the removal of pastoralists and their livestock from the Ngorongoro Crater, while wild herbivore diversity declined (Runyoro et al. 1995).

The Loliondo area is a part of the Serengeti ecosystem but, unlike the adjacent Serengeti National Park (SNP) or Ngorongoro Conservation Area (NCA), Loliondo comprises village lands managed by Village Councils. This gives local pastoralist communities a much greater jurisdictional control over land use decisions. Maddox (2003) carried out surveys of both herbivore and large carnivore populations in Loliondo, comparing species densities and abundance to areas inside NCA and SNP. He found no difference in wildlife diversity between the three areas, with animal biomass higher outside SNP, and concludes that there is 'no evidence that the presence of the Maasai and their livestock was particularly detrimental to any single species' and 'no evidence that livestock biomass replaces wild species biomass outside the park.' His findings echo earlier Serengeti ecosystem surveys analysed by Campbell and Borner (1995) which found 'no marked changes in density on either side of the protected area boundaries' dividing community-managed pastoralist lands in Loliondo from the state-managed SNP.

In summary, East African savannahs feature a combination of facilitative and competitive interactions between pastoralists and wildlife, but considerable evidence points to the ecological viability of co-existence between pastoralism and diverse and abundant populations of large mammals. Some studies find few negative spatial influences of livestock on wild ungulate distributions (e.g. Sitters et al. 2009), while other studies find a higher level of competition for forage or water in certain contexts (e.g. Ogutu et al. 2010). As noted above, both the presence and absence of livestock and pastoralists shapes East African rangelands in important ways and thus both positive and negative wildlife conservation influences arise from excluding pastoralists from areas such as national parks (Western and Gichohi 1994). One point on which there is no disagreement, though, is that

Table 1 Changes in population trends and overall numbers for large mammal herbivores (grazers only) in Ngorongoro Crater following eviction of resident pastoralists in 1974

\begin{tabular}{llll}
\hline Species & $\begin{array}{l}\text { Trend before } \\
\mathbf{1 9 7 4}\end{array}$ & $\begin{array}{l}\text { Trend after } \\
\mathbf{1 9 7 4}\end{array}$ & $\begin{array}{l}\text { Overall difference in population before and after } \\
\mathbf{1 9 7 4}\end{array}$ \\
\hline Wildebeest & Increase & Decline & Decline \\
Buffalo & Slight increase & Sharp increase & Increase \\
Hartebeest & Increase & Decline & Increase \\
Thomson's & Increase & Decline & Decline \\
gazelle & & & \\
Eland & Constant & Decline & Decline \\
Zebra & Constant & Decline & Decline \\
\hline
\end{tabular}

Adapted from Runyoro et al. (1995). 
pastoralist land uses are largely compatible with wildlife, whereas agriculture is not, and the preferences amongst local pastoralist communities for maintaining rangelands as common property has been and remains critical to the integrity of East African savannah ecosystems.

\section{Pastoralist land management and wildlife conservation in northern Tanzania}

Throughout the East African savannahs of Kenya and Tanzania, wildlife relies extensively on pastoralist lands, both those immediately adjacent to state-protected areas and across the broader landscape. Even in the Serengeti ecosystem, which includes over $25,000 \mathrm{~km}^{2}$ of state-protected areas, migrating wildlife relies extensively on community lands to the east, west, and north of the park (Thirgood et al. 2004). For example, Norton-Griffiths (1995) estimates that if the ecosystem's migratory wildebeest - roughly 1.2 million animals - could not access the private and communal lands to the north and east of Kenya's Maasai Mara National Reserve, which is the dry season refuge for these herds, the total number of animals the Serengeti ecosystem could support might be reduced by one-third. Indeed, large-scale wildlife declines of resident wildlife populations and the Loita-Mara wildebeest population of $56 \%$ and $81 \%$, respectively, have been attributed to land use changes on these private and communal lands (Homewood et al. 2001). In total, $65 \%$ of Kenya's wildlife is today found on community and private lands, with only $10 \%$ in national parks and about $25 \%$ accounted for by the Maasai Mara National Reserve alone (Western et al. 2009a). In other words, pastoralists and other landholders host the majority of Kenya's wildlife populations, sustaining the key asset in the national tourism industry (Norton-Griffiths 2007).

In northern Tanzania, wildlife similarly relies on dispersal areas and habitats outside state-protected areas although, in general, state-protected areas cover larger areas than in Kenya, with Tanzania having devoted about $30 \%$ of its total land area to protected areas where human residence is excluded (Brockington 2006).

Northern Tanzania contains two distinct major migratory wildlife systems, with some interaction and movement between the two (Figure 3). The largest number of wildlife lives within the Serengeti ecosystem, which as noted above extends to Kenya's Maasai Mara National Reserve and surrounding private lands. The Serengeti ecosystem is defined by the annual migration of some two to three million wildebeest, zebra, gazelles, and antelopes between dry season habitat in Kenya and the wet season grazing habitat of the Serengeti plains (Sinclair and Arcese 1995). Those plains lie along the border of the SNP and NCA.

When the herds of wildebeest move south from the Maasai Mara at the onset of the rains, usually occurring around November, they pass through the community lands of Loliondo. From the Serengeti plains, the herds also spill out onto the Salei plains north of the Gol Mountains, located on the village lands of Malambo and Engare Sero villages. These community-managed areas provide important wet season habitat (Thirgood et al. 2004). To the west of SNP, wildlife also moves outside the boundaries of SNP and the adjacent Ikorongo and Grumeti Game Reserves, onto village lands (now grouped together as the Ikona Wildlife Management Area) in Serengeti and Tarime Districts. Communities resident in these areas are however not transhumant pastoralists but agro-pastoralist members of the Kuria and Ikoma ethnic groups. These communities also prey extensively 


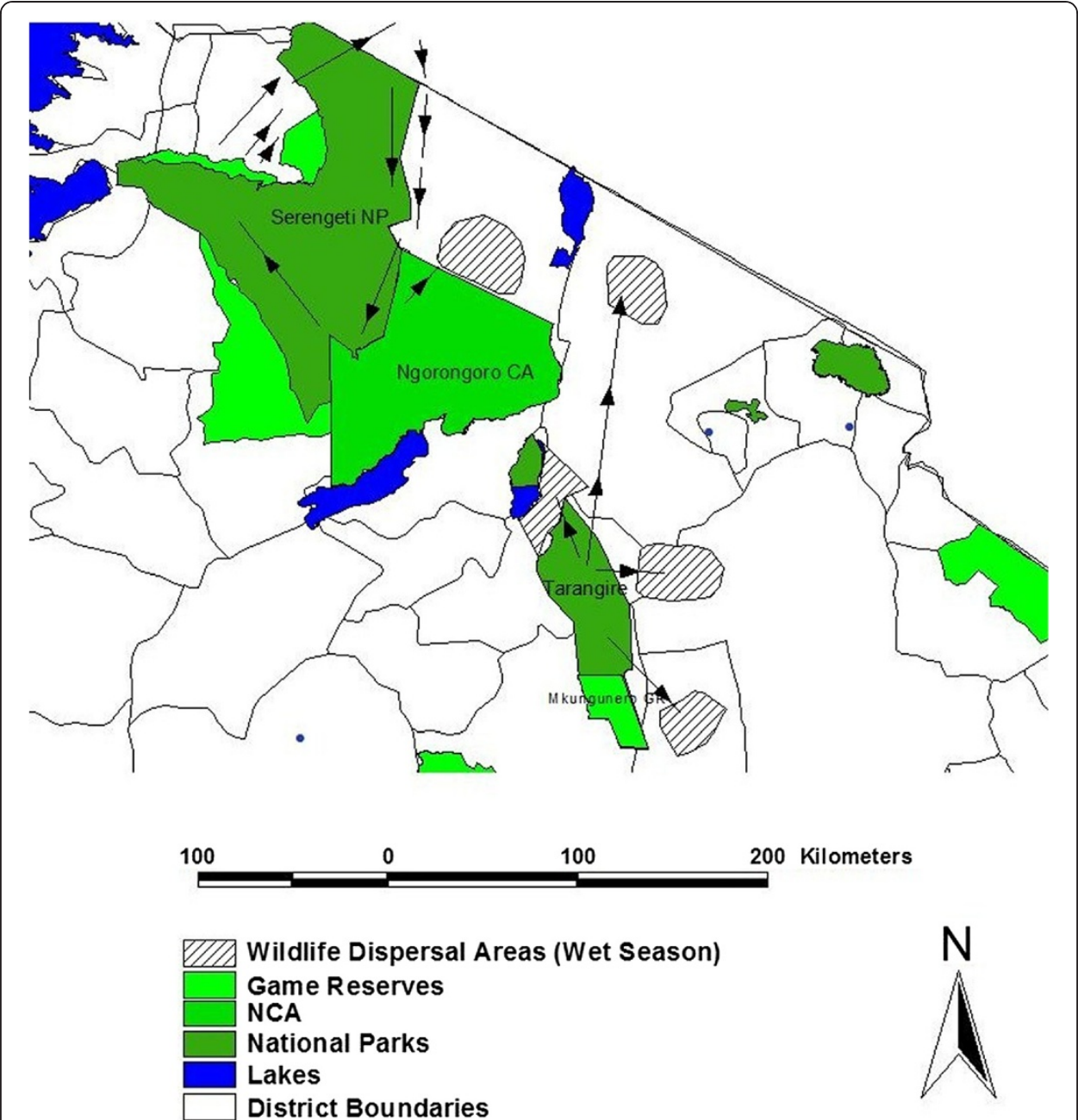

Figure 3 Migration routes and dispersal areas in protected areas and village lands in northern Tanzania's main wildlife areas. Adapted from TNRF (2008).

on wild ungulates as a source of food, in contrast to pastoralists in Loliondo, who do not traditionally eat wild animals. Consequently, wildlife densities to the west of the SNP show a marked decline outside the protected area's confines (Campbell and Borner 1995).

The second extensive wildlife migratory system in northern Tanzania is the Maasai steppe, which covers a vast stretch of about $35,000 \mathrm{~km}^{2}$, from near the Kenyan border around Lake Natron south through the Simanjiro plains and Tarangire National Park, to the arid Makame depression of northern Kiteto District (Sachedina and Nelson 2010). Unlike the Serengeti system to the west, the Maasai steppe is over $80 \%$ community and privately managed lands, with the vast majority being communal village lands. As the name of the ecosystem suggests, the Maasai steppe is inhabited almost entirely by pastoralist communities. The southern part of the steppe borders onto lands occupied by agricultural communities belonging to various non-pastoralist groups; in recent years, these groups of people have been extending smallholder agriculture into traditionally pastoralist areas in the southern Maasai steppe, leading to local conflicts over land use and tenure. 
The most important dry season refuge for wildlife of the Maasai steppe is located within Tarangire National Park, which contains the Tarangire River and the Silalo swamps, providing key water sources during droughts to water-dependent species such as elephant, buffalo, and zebra. During the wet season, these and other species disperse widely across the ecosystem (Borner 1985). Short grass plains to the west of Mount Kitumbeine and the Simanjiro plains to the east of Tarangire National Park both provide major dispersal habitats for zebra and wildebeest. In the 1970s, Kahurananga (1981) estimated the wet season populations of the Simanjiro plains at approximately 6,000 zebra and 10,000 wildebeest. Elephants move north out of Tarangire towards Lake Manyara and another small volcanic mountain, Esimingori, during the rains (TCP Tarangire Conservation Project 1997). Another subpopulation of elephants takes refuge in the southern part of Tarangire during droughts but primarily inhabits the Makame depression in the southern Maasai steppe. During the wet season, most wildlife is widely dispersed across the system, with few animals inside Tarangire National Park at that time. Although Tarangire National Park is the main site for large-scale tourism visitation in the system, as one of the leading destinations within the northern tourism circuit, wildlife is largely dependent on habitats located on community lands. The continued maintenance of these wet season habitats and migration corridors between key dry and wet season territories is consequently critical for wildlife and Tarangire's tourism product (Sachedina 2008).

These community lands are managed by local pastoralists for a range of livelihood purposes, but the overwhelming land management aim of pastoralist communities in both the Serengeti ecosystem and the Maasai steppe is oriented towards livestock production. As noted earlier, Maasai pastoralists in northern Tanzania manage their lands according to rules designating different pastures as wet season and as dry season grazing areas. Dry season reserved areas are particularly important in providing a 'grass bank' for livestock to consume during the long dry season of roughly June to October, when forage invariably becomes scarce and animals are stressed for water and nutrients. These dry season reserves are thus a key element of pastoralist livelihoods and natural resource management in northern Tanzania (UCRT 2010).

Traditionally, the use of dry season grazing reserves is governed by decisions made by customary Maasai leadership structures, which involve the leaders (ilegwanak) of the different age-sets meeting to decide when community members' herds may access the reserves. The period of time when entry will be allowed will depend on the amount of rain that has fallen in a given year and the condition of forage in the various grazing areas. In recent years, pastoralist communities have been able to formalize their customary land management systems through written village by-laws and land use plans. These measures, prepared based on Tanzania's local government and land policy and legislation, enable communities to formalize their traditional rules and translate them into a modern legalistic form which can be understood by outsiders and given some level of legal force. These locally developed land use plans and by-laws, underpinned by Tanzania's village-based system of local governance and land tenure, also provide the foundations for community-based natural resource management in Tanzania. This includes development of Village Land Forest Reserves under the 2002 Forest Act and Wildlife Management Areas (WMAs) defined by the 2009 Wildlife Conservation Act, as various mechanisms for communities to be granted user rights over these natural resources by the relevant state authorities. 
Dry season grazing reserves compose a variable but significant proportion of the communal village lands throughout northern Tanzania's pastoralist areas. These grazing reserves function as de facto village-level conserved areas or, to use the IUCN (World Conservation Union) terminology, as Community Conserved Areas (Kothari 2006). The maintenance of reserved grazing areas in pastoralist villages, managed at the communal scale, is a key reason why extensive unfragmented savannah landscapes continue to exist in northern Tanzania, across vast areas with little formal governmental regulation of land uses such as the Maasai steppe. Traditional pastoralist land use practices and designations give northern Tanzania much of its wild or wilderness character, which in turn is a central reason why this landscape both supports wildlife and attracts foreign tourists to the degree that it does.

These grazing reserves also physically overlap with many of the key wildlife habitats and dispersal areas in northern Tanzania. For example, in Loliondo, dry season grazing areas are situated in the western portion of the seven villages whose lands lie adjacent to SNP's eastern boundary (Ngoitiko et al. 2010). Pastoralists' dry season grazing reserves therefore provide a de facto buffer zone under local management which helps to conserve wildlife populations in western Loliondo. This includes the resident wildlife populations noted by Maddox (Maddox and Thomas 2003) and others, as well as the southbound migration route of the ecosystem's large ungulate herds. To the east, when wildebeest move onto the Salei plains during the wet season, they utilize dry season grazing reserved areas in Engare Sero village, which straddles the Rift Valley escarpment from Salei down to Lake Natron.

In the Maasai steppe, key habitats such as the Simanjiro plains are partially protected by traditional dry season grazing reserves. For example, Terrat village, which holds about onethird of the Simanjiro plains within its village land boundaries, traditionally allows livestock onto the plains from July up until around January (Nelson et al. 2010). In January, if rain has fallen, wildebeest usually begin calving on the plains, and livestock move away until the dry season grazing period begins again in July (approximately). To the west and southwest, Loiborserrit and Emboreet villages situate their dry season grazing reserves along the eastern border of Tarangire National Park, in an area that provides extensive habitat for buffalo, elephant, and other large mammals moving back and forth across the unseen park boundary. As in Loliondo, these local customary land management practices serve to conserve a large expanse of wildlife habitat adjacent to the park, effectively extending the area conserved and preventing the encroachment of agriculture against the park boundary. During the last 20 years, these traditional designations have been reinforced by a range of formal local governance and conservation measures, including local land use plans and bylaws, community tourism concession agreements with private operators, and, in Terrat village, a unique land easement agreement which pays the village to maintain their portion of the Simanjiro plains as dry season grazing reserve and to formally prohibit agriculture (Sachedina and Nelson 2010).

\section{Estimating the economic value of pastoralist land use practices to tourism}

Pastoralist land management practices across northern Tanzania function to conserve important wildlife habitats, complementing state-protected areas and enabling wildlife to continue moving between seasonal habitats across expansive ecosystems. These customary land use and management practices clearly contribute to the conservation of 
wildlife habitat and wildlife populations in northern Tanzanian ecosystems. Moreover, these ecosystem services have an important economic dimension, given the scale and importance of northern Tanzania's tourism industry.

Tanzania's tourism industry generated an estimated $\$ 900$ million in direct revenue and an estimated \$1.6 billion in indirect economic value in 2008 (Mitchell et al. 2009). The northern safari circuit, which includes Serengeti, Lake Manyara, and Tarangire National Parks and the Ngorongoro Conservation Area (NCA, and adjacent pastoralist lands, attracts about 300,000 international tourists and total in-country tourist expenditure estimated at around $\$ 550$ million annually (Mitchell et al. 2009). In other words, the northern safari circuit, which relies entirely on wildlife using both state-protected areas and local pastoralists' lands (even if most tourism activity is situated within the former rather than the latter), accounts for over $60 \%$ of Tanzania's total national tourism industry.

It is clear that by conserving large proportions of northern Tanzania's wildlife ecosystems, local pastoralist communities collectively make an important contribution to the national and regional economy. But, precisely how much do these ecological services contribute to the overall wildlife-based tourism economy? What proportion of total northern circuit tourism earnings is attributable to pastoralist land management practices?

In answering this question, one faces two basic challenges. First, the quality of available data on tourism revenues and aggregate economic impacts is limited and somewhat dated. This article utilizes the most reliable and informative statistics and analyses, building in particular on the northern circuit tourism value chain analysis produced by Mitchell et al. (2009). Second, the role of pastoralist land use practices varies across individual landscapes within northern Tanzania. In the Maasai steppe, for instance, wildlife that spends the dry season inside Tarangire National Park is dependent through the entire wet season, including for calving grounds, on community lands outside the park. In the Serengeti ecosystem, state-protected areas cover a much greater proportion of the total ecosystem. Thus, the economic contribution of pastoralist land uses across northern Tanzania needs to be weighted according to the relative importance of pastoralist land uses in these different ecosystems anchoring the regional tourism industry.

Using the total number of tourist visitors to the different areas (NCA and SNP for the Serengeti ecosystem; TNP and LMNP for the Maasai steppe ecosystem), the proportional values of the two systems in relation to the northern circuit's total direct economic value of $\$ 550$ million can be estimated. ${ }^{a}$ Dividing this total between the two ecosystems that comprise the northern circuit, based on visitor numbers at the different areas, results in a total value attributable to the Maasai steppe of about $\$ 153$ million, and for the Serengeti ecosystem (including $25 \%$ of NCA revenue) of $\$ 224$ million (Table 2). ${ }^{\mathrm{b}}$

In the Maasai steppe, over $80 \%$ of the total wildlife range lies on private and communal lands, the vast majority of it within predominantly pastoralist villages. However, the key wildlife habitats comprise a smaller area and are focused on areas such as the Simanjiro plains and similar short grass plains near Mount Kitumbeine for herds of zebra and wildebeest, as well as areas such as Lolkisale and Makame for elephants. We can conservatively estimate that about $50 \%$ of the key habitats supporting wildlife in the Maasai steppe is managed by pastoralists on village lands in this ecosystem and that, if all pastoralist lands were unavailable for use by wildlife, the total value of the ecosystem in terms of wildlife-based tourism would decline by half. 
Table 2 Proportional value of different areas (national parks and NCA) in the northern circuit

\begin{tabular}{|c|c|c|c|}
\hline Area & $\begin{array}{l}\text { Number of } \\
\text { tourists }\end{array}$ & $\begin{array}{l}\text { Proportion of northern } \\
\text { circuit visitors (\%) }\end{array}$ & $\begin{array}{l}\text { Estimated proportion of total northern circuit } \\
\text { revenue generation }\end{array}$ \\
\hline $\begin{array}{l}\text { Lake } \\
\text { Manyara } \\
\text { NP }\end{array}$ & 141,226 & 16 & $\$ 88,957,628$ \\
\hline $\begin{array}{l}\text { Serengeti } \\
\mathrm{NP}\end{array}$ & 265,880 & 31 & $\$ 167,476,628$ \\
\hline $\begin{array}{l}\text { Tarangire } \\
\text { NP }\end{array}$ & 102,562 & 12 & $\$ 64,603,347$ \\
\hline NCA & 360,000 & 41 & $\$ 226,762,397$ \\
\hline \multicolumn{3}{|c|}{ Total value attributable to Maasai steppe } & $\$ 153,560,975$ \\
\hline \multicolumn{3}{|c|}{$\begin{array}{l}\text { Total value attributable to Serengeti ecosystem (including } \\
25 \% \text { NCA) }\end{array}$} & $\$ 224,167,227$ \\
\hline
\end{tabular}

This is based on the proportion of northern circuit visitor numbers at each area. Adapted from TANAPA (2007) and Mitchell et al. (2009).

In the Serengeti ecosystem, the proportion of wildlife habitat provided by pastoralist communities' village lands is much lower. Thirgood et al. (2004), using radio-telemetry studies of wildebeest during 1999 and 2000, estimate that the wildebeest herds spend about 3\% of their total time in Loliondo and the Salei plains, which are the main pastoralist-controlled lands in the Serengeti ecosystem. ${ }^{\mathrm{c}}$ We will therefore estimate the relative contribution that pastoralists make to the conservation of the Serengeti ecosystem at $3 \% .^{\mathrm{d}}$

The approximate figures of 50\% of habitat in the Maasai steppe, and 3\% in the Serengeti, as representing the degree to which wildlife in these ecosystems depend on pastoralist lands adjacent to the state-protected areas enables one to attach valuation figures, based on the total revenue generated through tourism, to pastoralist lands in these areas. This leads to an estimate of the total economic value in relation to wildlife conservation and tourism revenue of approximately $\$ 83.5$ million annually (Table 3 ). This figure is somewhat imprecise, and uses a cobbled-together methodology in light of limitations in the available data, but nevertheless demonstrates that the economic contribution that pastoralists make through their land management practices in relation to Tanzania's wildlife-based tourism industry is substantial.

It should also be noted that this estimate can be considered a minimum valuation of pastoralist contributions to the wildlife-tourism economy. These estimates focus on the northern safari circuit's two main ecosystems - the Serengeti and the Maasai steppe - but other less significant forms of wildlife utilization also generate revenue. For example, most pastoralist lands are allocated by the central government as tourist hunting concessions, which as of 2003 generated an average of $\$ 40 / \mathrm{km}^{2}$ in direct government revenue (Baldus et al. 2004). Nearly all of such predominantly pastoralist districts such as Longido, Monduli, and Simanjiro are allocated as hunting concessions, covering an area of at least $35,000 \mathrm{~km}^{2}$. The revenue from tourist hunting in pastoralist areas, which is largely enabled by the coexistence of pastoralist communities with diverse and relatively abundant populations of large mammals on their lands, is therefore at least $\$ 1.4$ million annually. Due to recent raises in hunting fees, the current actual total is in all likelihood several times that amount in direct revenue alone, without including any indirect benefits or economic multipliers. 
Table 3 Estimated value of pastoralist lands to wildlife-based tourism in the Maasai steppe and Serengeti ecosystems

\begin{tabular}{lll}
\hline Ecosystem & $\begin{array}{l}\text { Degree of wildlife reliance on } \\
\text { pastoralist lands (\%) }\end{array}$ & $\begin{array}{l}\text { Economic contribution of pastoralist lands as a } \\
\text { percentage of total tourism earnings }\end{array}$ \\
\hline $\begin{array}{l}\text { Maasai } \\
\text { steppe }\end{array}$ & 50 & $\$ 76,780,487.73$ \\
$\begin{array}{l}\text { Serengeti } \\
\text { ecosystem }\end{array}$ & 3 & $\$ 6,725,016.81$ \\
Total & & $\$ 83,505,504.54$ \\
\hline
\end{tabular}

Based on the relative degree that wildlife relies on pastoralist lands outside the boundaries of state-protected areas.

\section{Policy implications}

It has long been recognized that pastoralist lands and land use practices provide much of the habitat that migratory wildlife in East African national parks continues to rely on for seasonal habitat requirements (Myers 1972; Western 1982). As northern Tanzania's tourism industry has grown, with the northern safari circuit comprising about $6 \%$ of the country's total national economy, the economic importance of pastoralist conservation practices in these extensive ecosystems has increased considerably. This highlights the strategic economic importance to the Tanzanian state of pastoralist land use practices, including in particular the rights to zone land for seasonal uses and continue to practice mobility as a key element of management systems.

Given the economic importance of pastoralist land management practices, Tanzanian policy in sectors such as land, livestock, wildlife, and tourism should take into account these strategic economic considerations and support the ability of local pastoralist communities to maintain communal pastures and reserved grazing areas. The key, from an economic and development policy perspective, is to craft policy and legal measures that enable pastoralist rangelands to continue to maintain wildlife and livestock in communally managed rangelands. Land use changes that result in conversion of these pastoralist rangelands to agricultural cultivation represent the foremost threat to wildlife populations and, in turn, the continued market advantage Tanzania enjoys in high-end wildlife tourism.

It is thus highly notable, and in an economic policy sense quite perverse, that Tanzanian policy generally provides few incentives for pastoralists to continue to tolerate or conserve wildlife on their lands, and nor are policy measures effectively geared towards encouraging pastoralists to maintain the communal land holdings and mobile transhumant production systems that underpin the continued co-existence of wildlife and livestock in these rangelands.

\section{Land tenure}

A key issue for the future of Tanzanian savannah ecosystems will be the ability of local pastoralist communities to continue managing rangelands at the communal scale, rather than fragmenting rangelands into individually owned properties. Converting rangeland from communal pastures to individual properties will likely prevent the movements across large areas of land that both livestock and wildlife in semi-arid landscapes depend upon. Tanzania needs look no further for a possible future scenario than Kenyan Maasailand to the north, where the former Group Ranches have been extensively subdivided into individual land holdings which are of insufficient size to support pastoralist production (Kimani and Pickard 1998; Western et al. 2009b). These processes of subdivision have been driven by weaknesses in the governance and design of the Group Ranches as collective entities, 
resulting in progressive loss of communal land through decisions made by local elites on the Group Ranch governing bodies (Mwangi 2007). This process of rangeland fragmentation, driven by past policy design choices by the Kenyan state, has dire implications for wildlife in key areas such as the Maasai Mara and Amboseli - also the country's most valuable wildlife tourism sites - and there is evidence of declining wildlife populations due to these land use changes (Homewood et al. 2001).

Unlike Kenya, Tanzania's land tenure laws and policies provide a relatively enabling framework for communal land management. The Land Act and Village Land Act, passed in 1999, make customary rights in land legally equivalent to granted rights and specifically cater for rights to be held and exercised collectively (Alden and Liz 2003). The Village Land Act also provides for villages to zone their land between individual and communal areas, which supports land use planning measures that reserve different seasonal grazing areas, as has been done in many northern Tanzanian pastoralist communities (UCRT Ujamaa Community Resource Team 2010).

However, the Land Act also includes 'unused community lands' within its definition of 'general lands' which are under the control of the Ministry of Lands and may be allocated for use to applicants. Seasonally used pastoralist lands are often perceived by outsiders as 'unused' and therefore may be subject to attempts by government authorities to allocate them in this way (Mattee and Shem 2006). Lands that pastoralists have traditionally used and set aside as dry season grazing reserves are often considered unused, and recently, during certain land disputes, notably the land conflict that has occurred in Loliondo since 2009, government has argued that such areas are not in fact village lands (TNRF and Maliasili Initiatives 2011). This undermines the security of communal pastoralist land holdings and encourages individualization and cultivation of pastoralist lands, in a process that Sachedina (2008) terms as 'branding the land' with the plough so that use and occupancy can decisively be documented.

\section{Livestock}

Tanzanian livestock policy and legal reforms in recent years have consistently emphasized modernization and increasing commercial meat, milk, and hide production. These modernization models generally prioritize development of large-scale, privately owned ranches as the key to increasing commercial production and view traditional pastoralist production as inefficient and relatively archaic (Mattee and Shem 2006).

The individualization or spread of privately owned ranches in northern Tanzania would have significant costs in relation to the tourism industry, due to the impacts on wildlife of rangeland fragmentation. When private ranches are carved out of communal pastures, the private parcels tend to be much smaller and are often demarcated through fencing. It is debatable if the development of smaller, privately held landholdings out of larger scale, communal pastures would lead to more commercial production of livestock in northern Tanzania. However, it is indisputable that such changes would have major costs in terms of wildlife populations and tourism enterprises, as Kenya's experience with rangeland fragmentation illustrates (Norton-Griffiths 2007). Rather than promoting private ranch-based livestock sector development models, policymakers should focus on measures that enable pastoralist livestock producers to improve their production and profit margins, such as enhanced market information or veterinary services. 


\section{Wildlife and tourism}

While pastoralists continue to provide valuable ecosystem services in support of Tanzania's tourism industry and related wildlife conservation interests, the wildlife and tourism sectors continue their long legacy of failing to reciprocate in their provisions as they relate to pastoralists. Historically, pastoralists have lost key lands and resources to the stateprotected areas and continue to lose access to areas. For example, the Mkungunero Game Reserve's creation in the late 1990s in the southern Maasai steppe created conflicts with local pastoralist villages and widespread apprehension about expanding protected areas and land loss in the area (Sachedina 2008). The allocation of centrally managed tourist hunting concessions on community lands is a widespread source of conflict and results in local people having insecure rights over land and resources in areas such as the Maasai steppe (Sachedina 2008). Pastoralists in Loliondo and the Maasai steppe have also had recurrent disputes with protected area authorities regarding the boundaries of their lands and national parks (Goldman 2009, 2011).

These tensions between protected area authorities and local communities create perverse incentives which are not conducive to maintaining integrated wildlife and livestock land uses in pastoralist rangelands. For example, in Emboreet village, on the border of Tarangire National Park, there is evidence that local pastoralists have expanded farming in key wildlife habitats as a response to fears that external agencies will appropriate their land for purposes of wildlife conservation (Sachedina 2008).

While the national park service, TANAPA, does maintain some benefit-sharing programmes with surrounding communities, these are neither of the scale nor of the type needed to positively influence neighbouring pastoralists to support ecosystem-scale conservation objectives through the necessary land use choices. For example, Tarangire National Park provided average benefits (usually in the form of contributions to district or villagelevel social service or infrastructure projects) to Simanjiro District of $\$ 30,470$; at this time, the park's annual income from tourism was around \$1.5 million/year (reaching \$2.1 million by 2005 and now consistently above $\$ 2$ million/year) (Sachedina and Nelson 2010). This represents an investment - designed explicitly to encourage support for conservation among neighbouring communities - of about $2 \%$ of revenues in what is the single most important dispersal and breeding area for much of the wildlife found in Tarangire. As Sachedina and Nelson (2010) describe, it is not only the limited amount of funds invested in neighbouring communities, but the way these funds are provided as in effect unconditional donations to development projects that are not in any way tied to local land use decisions or conservation actions, that undermines their impact. By contrast, an investment by a coalition of private tourism operators of a limited amount of funding in a conditional agreement with one village on the Simanjiro plains which agreed not to farm within its traditional grazing area has reinforced local incentives not to convert key wildlife habitat to agriculture (Nelson et al. 2010). In order to protect its own long-term financial interests in wildlife and tourism, it would be advisable for TANAPA to make more targeted investments in supporting pastoralist land uses in areas surrounding its parks and to use conditional payment for ecosystem services agreements to achieve such ends.

At the level of wider wildlife and tourism policy, recent years have witnessed a perverse trend towards increasing restrictions on the ability of local communities, such as pastoralists living adjacent to Tarangire and SNPs, to capture revenue directly from concessionary agreements with private tourism operators. In 2007, the government introduced new 
regulations for fee-sharing systems for tourism occurring on community lands, effectively taxing these agreements at a punitive level in excess of $50 \%$, thus greatly reducing revenues that communities receive from such arrangements (Snyder et al. 2011).

At the same time, Tanzania has moved forward with the development of WMAs, areas set aside on village lands by communities where the government grants communities formal user rights over wildlife so that they can capture benefits from commercial uses such as tourism and hunting. However, the development of WMAs has been limited by complex procedural requirements, limited investments in local capacity building, and benefit-sharing arrangements that still give government $35 \%$ of total revenues and do not devolve control over tourist hunting to the local level (Nelson 2007; Sulle et al. 2011). In some areas such as Loliondo, pastoralists have opted not to implement proposed WMAs due to concerns about these factors as well as the security of grazing areas under the wildlife-focused WMA framework (Ngoitiko et al. 2010). In theory, WMAs should be able to reconcile local livelihoods and pastoralist land use objectives with wildlife conservation, particularly given the historic co-existence of wildlife with pastoralist land use systems. It would be economically rational, from the perspective of the state's interests in the larger wildlife systems that these WMAs form a part of, for the state to give communities $100 \%$ of revenues from WMAs ${ }^{\mathrm{e}}$ and for the state to facilitate greater opportunities from tourism and tourist hunting to generate more revenue and ensure WMAs are competitive forms of land use. This would enhance the likelihood that pastoralist communities embrace the WMA option and that WMAs create effective incentives to maintain integrated wildlife and livestock land uses.

\section{Conclusions}

The ability of transhumant pastoralist livestock production to co-exist alongside a high level of diversity and abundance of wild ungulates and other large mammals in northern Tanzania is not only a key to wildlife conservation in the region but also to the area's role as the driver of Tanzania's tourism industry, which now comprises around $11 \%$ of the country's total economic production. Pastoralists in northern Tanzania, through their land use choices and specific management practices such as the maintenance of dry season grazing reserves and protection of forests and woodlands, provide what is in reality an increasingly commercially valued ecosystem service.

Despite the value pastoralist land uses provide to the growing wildlife tourism industry, Tanzanian policies, particularly wildlife policy and legislation, continue to place constraints on pastoralist land uses, particularly in terms of the maintenance of communal land uses and ability of communities to capture revenues from tourism. These policy choices serve to discourage continued collective pastoralist land uses and play a role in the expansion of agricultural cultivation and fragmentation of communal rangelands. Tanzanian policy is inefficient in the sense that it discourages local land use choices that help to support a critical segment of the national economy. A more rational and productive set of policy choices would not only remove disincentives to pastoralist land uses, but also develop mechanisms for actively rewarding them, for example, through payments for ecosystem services that better link revenues from tourism with local communities whose land uses support wildlife and tourism. Tanzanian policymakers, pastoralist communities, wildlife conservation interests, and the tourism industry share a common economic interest in the design and deployment of such mechanisms so that 
pastoralist land uses will continue to produce the ecosystem services that they presently provide.

\section{Competing interests}

The author declares that he has no competing interests.

\section{Author's information}

FN is the Executive Director of Maliasili Initiatives, a US-based non-profit organization that works with local partner organizations in East Africa to advance sustainable natural resource management through local rights and incentives. He lived and worked in northern Tanzania for 11 years, working on issues at the intersection of rural development, political economy, natural resource conservation, and social justice. He recently edited the volume Community Rights, Conservation and Contested Land: The Politics of Natural Resource Governance in Africa (Copyright Earthscan, 2010).

\section{Endnotes}

This figure is taken from Mitchell et al. (2009) and represents the total revenue expenditure by the approximately 300,000 foreign visitors to the northern circuit.

${ }^{b}$ NCA includes both a large portion of the Serengeti plains, which are a part of the greater Serengeti ecosystem, and the relatively enclosed Ngorongoro Crater, the primary tourism site within NCA, where wildlife is generally resident and does follow the migratory patterns of wildlife elsewhere in the Serengeti system. If we only include $25 \%$ of the total revenue from NCA, then we obtain a perhaps more realistic figure for the Serengeti ecosystem that excludes Ngorongoro Crater of about $\$ 224$ million.

'Although non-pastoralist community lands to the west of SNP, in the Ikoma area, and to the north of the Maasai Mara National Reserve in Kenya are more important to wildebeest and other migratory wildlife, these areas are not included in the scope of this study, which is concerned only with pastoralist lands in Tanzania.

${ }^{\mathrm{d}}$ This figure is also conservative because it does not in any way factor in the role pastoralists have played for hundreds of years in maintaining the landscape of the NCA, which, unlike the national parks is a multiple land use area with over 50,000 resident Maasai pastoralist residents (Homewood and Rodgers 1991). However, since pastoralists in this area, unlike in Loliondo, do not have clear rights over land management decisions and are not able to make and enforce their own land use plans due to regulatory powers exercised by the Ngorongoro Conservation Area Authority (Shivji et al. 1998), it is difficult to credit pastoralists in NCA with responsibility for land management decisions that contribute to conservation in the way that one may in other pastoralist areas.

e For example, in the notionally similar communal conservancies of Namibia, communities are legally entitled to $100 \%$ of all revenue generated in the conservancies.

\section{Acknowledgements}

This research was originally carried out with the support from the International Institute for Environment and Development. In particular, Ced Hesse and James MacGregor provided valuable advice and support in the initial design of the study and commented on earlier versions of this article. Two anonymous reviewers also provided helpful comments and suggestions.

Received: 18 October 2011 Accepted: 27 January 2012

Published: 28 September 2012

\section{References}

Alden, W., \& Liz, A. (2003). Community-based land tenure management: questions and answers about Tanzania's New Village Land Act. London: International Institute for Environment and Development.

Baldus, Rolf, D., \& Cauldwell, A. E. (2004). Tourist hunting and its role in development of wildlife management areas in Tanzania. Paris: Paper presented to the Sixth International Game Ranching Symposium. 6-9 July, 2004.

Barrow, E. (1988). Trees and pastoralists: the case of the Pokot and Turkana. Overseas Development Institute, Social Forestry Network, Network Paper 6b. London: ODI.

Behnke, R. H., Scoones, I., \& Kerven, C. (1993). Range ecology at disequilibrium: new models of natural variability and pastoral adaptation in African savannas. London: Overseas Development Institute.

Bell, R. H. V. (1971). A grazing system in the Serengeti. Scientific American, 224, 86-93.

Berkes, F. (1989). Common property resources: ecology and community-based sustainable development. London: Belhaven Press. Borner, M. (1985). The increasing isolation of Tarangire National Park. Oryx, 19, 91-96.

Bourn, D., \& Blench, R. (1999). Can livestock and wildlife co-exist? An interdisciplinary approach. Oxford: Overseas Development Institute.

Brockington, D. (2006). The politics and ethnography of environmentalisms in Tanzania. African Affairs, 105, 97-116.

Campbell, K., \& Borner, M. (1995). Population trends and distribution of Serengeti herbivores: implications for management. In A. R. E. Sinclair \& P. Arcese (Eds.), Serengeti II: dynamics, management, and conservation of an ecosystem (pp. 117-145). Chicago: University of Chicago Press.

Collet, D. (1987). Pastoralists and wildlife: image and reality in Kenya Maasailand. In D. Anderson \& R. Grove (Eds.), Conservation in Africa: people, policies, and practice (pp. 129-148). Cambridge: Cambridge University Press.

Dodd, J. L. (1994). Desertification and degradation in sub-Saharan Africa: the role of livestock. Bioscience, 44(1), 28-34.

Du Toit, J. (2011). Coexisting with cattle. Science, 333, 1710-1711.

Ellis, J. E., David, M., \& Swift. (1988). Stability of African pastoral ecosystems: alternate paradigms and implications for development. Journal of Range Management, 41(6), 450-459.

Gichohi, H. (1992). The effects of fire and grazing on grasslands of Nairobi National Park. MSc Thesis. Nairobi: University of Nairobi.

Goldman, M. (2009). Constructing connectivity? Conservation corridors and conservation politics in East African rangelands. Annals of the Association of American Geographers, 99(2), 335-359. 
Goldman, M. (2011). Strangers in their own land: Maasai and wildlife conservation in Northern Tanzania. Conservation and Society, 9(1), 65-79.

Grzimek, B., \& Grzimek, M. (1960). Serengeti shall not die. New York: E.P. Dutton \& Co., Inc.

Hardin, G. (1968). The tragedy of the commons. Science, 162, 1243-1248.

Hayes, T. M. (2006). Parks, people, and forest protection: an institutional assessment of the effectiveness of protected areas. World Development, 34, 2064-2075.

Homewood, K. M., \& Rodgers, W. A. (1991). Maasailand ecology: pastoralist development and wildlife conservation in Ngorongoro, Tanzania. Cambridge: Cambridge University Press.

Homewood, K., Lambin, E. F., Coast, E., Kariuki, A., Kikula, I., Kivelia, J., Said, M., Serneels, S., \& Thompson, M. (2001). Long-term changes in Serengeti-Mara wildebeest and land cover: pastoralism, population, or policies? PNAS, 98(22), 12544-12549.

Kahurananga, J. (1981). Population estimates, densities and biomass of large herbivores in Simanjiro Plains, northern Tanzania. African Journal of Ecology, 19, 225-238.

Kimani, K., \& Pickard, J. (1998). Recent trends and implications of group ranch subdivision and fragmentation in Kajiado District, Kenya. The Geographical Journal, 164, 202-213.

Kothari, A. (2006). Community conserved areas: towards ecological and livelihood security. Parks, 16, 3-13.

Lamprey, H. (1983). Pastoralism yesterday and today: the overgrazing problem. In F. Bourliere (Ed.), Tropical Savannas: ecosystems of the world (pp. 643-666). Amsterdam: Elsevier.

Maddox, \& Thomas, M. (2003). The ecology of cheetahs and other large carnivores in a pastoralist-dominated buffer zone. PhD Thesis. London: University College, London and Institute of Zoology.

Mattee, A. Z., \& Shem, M. (2006). Ambivalence and contradiction: a review of the policy environment in Tanzania in relation to pastoralism. Drylands Issue Paper No. 140. London: International Institute for Environment and Development.

McCabe, J. T. (1990). Turkana pastoralism: a case against the Tragedy of the Commons. Human Ecology, 18(1), 81-103.

Mitchell, J., Jodie, K., \& Jenny, L. (2009). Making success work for the poor: Package tourism in northern Tanzania. Overseas Development Institute and SNV. http://www.odi.org.uk/resources/docs/4203.pdf. Accessed. 14/7/2012.

Mwangi, E. (2007). The puzzle of group ranch subdivision in Kenya's Maasailand. Development and Change, 38(5), 889-910.

Myers, N. (1972). National parks in savannah Africa. Science, 178, 1255-1263.

Nelson, F. (2007). Emergent or illusory? Community wildlife management in Tanzania. Drylands Issue Paper No. 146. London: International Institute for Environment and Development.

Nelson, F., Foley, C., Lara, S., Foley, A. L., Loure, E., Peterson, D., Peterson, M., Peterson, T., Sachedina, H., \& Williams, A. (2010). Payments for ecosystem services as a framework for community-based conservation in northern Tanzania. Conservation Biology, 24(1), 78-85.

Neumann, R. P. (1998). Imposing wilderness: struggles over livelihood and nature preservation in Africa. Berkeley: University of California Press.

Ngoitiko, M., Sinandei, M., Meitaya, P., \& Nelson, F. (2010). Pastoral activists: negotiating power imbalances in the Tanzanian Serengeti. In F. Nelson (Ed.), Community rights, conservation and contested land: the politics of natural resource governance in Africa (pp. 269-289). London: Earthscan.

Norton-Griffiths, M. (1995). Economic incentives to develop the rangelands of the Serengeti: implications for wildlife conservation. In A. R. E. Sinclair \& P. Arcese (Eds.), Serengeti Il: dynamics, management, and conservation of an ecosystem (pp. 588-604). Chicago: University of Chicago Press.

Norton-Griffiths, M. (2007). How many wildebeest do you need? World Economics, 8, 41-64.

Odadi, Wilfred, O., Karachi, M. K., Abdulrazak, S. A., \& Young, T. P. (2011). African wild ungulates compete with or facilitate cattle depending on season. Science 3, 333, 1753-1755.

Ogutu, J. O., Piepho, H.-P., Robin, S., Reid, M. E., Rainy, R. L., Kruska, J. S., Worden, M. N., \& Thompson Hobbs., N. (2010). Large herbivore responses to water and settlements in savannas. Ecological Monographs, 80(2), 241-266.

Ostrom, E. (1990). Governing the commons: the evolution of institutions for collective action. Cambridge: Cambridge University Press.

Ostrom, E., \& Nagendra, H. (2006). Insights on linking forests, trees, and people from the air, on the ground, and in the laboratory. PNAS, 103, 19224-19231.

Pratt, D. J., \& Gwynne, M. D. (1977). Rangeland management and ecology in East Africa. London: Hodder and Stoughton.

Runyoro, Victor, A., Heribert, H., Chausi, E. B., \& Moehlman, P. D. (1995). Long-term trends in the herbivore populations of the Ngorongoro Crater, Tanzania. In A. R. E. Sinclair \& P. Arcese (Eds.), Serengeti ll: dynamics, management, and conservation of an ecosystem (pp. 146-168). Chicago: University of Chicago Press.

Sachedina, H. (2008). Wildlife is our oil: conservation, livelihoods and NGOs in the Tarangire ecosystem, Tanzania. UK: PhD thesis, University of Oxford.

Sachedina, H., \& Nelson, F. (2010). Protected areas and community incentives in savannah ecosystems: a case study of Tanzania's Maasai Steppe. Oryx, 44, 390-398.

Scoones, I. (1995). Living with uncertainty: new directions in pastoral development in Africa. London: Intermediate Technology Publications.

Shivji, Issa, G., \& Kapinga, W. B. (1998). Maasai rights in Ngorongoro, Tanzania. London: IIED/HAKIARDHI.

Sinclair, A. R. E., \& Arcese, P. (1995). Serengeti ll: dynamics, management, and conservation of an ecosystem. Chicago: University of Chicago Press.

Sitters, J., Ignas MA, H., Milena, H., \& Gordon SO, O. (2009). Herded cattle and wild grazers partition water but share forage resources during dry years in East African savannas. Biological Conservation, 142, 738-750.

Snyder, Katherine, A., \& Sulle, E. B. (2011). Tourism in Maasai communities: a chance to improve livelihoods? Journal of Sustainable Tourism, 19(8), 935-951.

Sulle, E., Lektita, E., \& Nelson, F. (2011). From promise to performance? Wildlife Management Areas in Northern Tanzania. Arusha: Tanzania Natural Resource Forum, Ujamaa Community Resource Team and Maliasili Initiatives.

TANAPA (Tanzania National Parks). (2007). Annual report and financial statements 2006/07. Arusha: TANAPA.

TCP (Tarangire Conservation Project). (1997). Analysis of migratory movements of large mammals and their interaction with human activities in the Tarangire Area in Tanzania as a contribution to a conservation and sustainable development strategy. Final Report: Explanatory Section, Arusha. 
Thirgood, S., Anna, M., Sebastian, T., Grant, H., Ephraim, M., Titus, M., Morris, K., John, F., Anthony RE, S., \& Markus, B. (2004). Can parks protect migratory ungulates? The case of the Serengeti wildebeest. Animal Conservation, 7, 113-120.

TNRF (Tanzania Natural Resource Forum). (2008). Wildlife for all Tanzanians: stopping the loss, nurturing the resource and widening the benefits. An information pack and policy recommendations. Arusha: TNRF.

TNRF and Maliasili Initiatives. (2011). Integrating pastoralist livelihoods and wildlife conservation? Options for land use and conflict resolution in Loliondo division, Ngorongoro District. Arusha: Tanzania Natural Resource Forum.

UCRT (Ujamaa Community Resource Team). (2010). Participatory land use planning as a tool for community empowerment in northern Tanzania. Gatekeeper Series No. 147. London: International Institute for Environment and Development.

Western, D. (1982). Amboseli National Park: enlisting landowners to conserve migratory wildlife. Ambio, 11(5), 302-308.

Western, D. (1989). Conservation without parks: wildlife in the rural landscape. In D. Western \& M. Pearl (Eds.), Conservation for the twenty-first century (pp. 158-165). Oxford: Oxford University Press.

Western, D., \& Gichohi, H. (1994). Segregation effects and the impoverishment of savannah park: the case for ecosystem viability analysis. African Journal of Ecology, 31, 269-281.

Western, D., Russell, S., \& Cuthill, I. (2009). The status of wildlife in protected areas compared to non-protected areas of Kenya. PLoS ONE, 4(7), e6140. doi:10.1371/journal.pone.0006140.

Western, D., Groom, R., \& Worden, J. (2009). The impact of subdivision and sedentarization of pastoral lands on wildlife in an African savanna ecosystem. Biological Conservation, 142, 2538-2546.

doi:10.1186/2041-7136-2-15

Cite this article as: Nelson: Natural conservationists? Evaluating the impact of pastoralist land use practices on

Tanzania's wildlife economy. Pastoralism: Research, Policy and Practice 2012 2:15.

\section{Submit your manuscript to a SpringerOpen ${ }^{\circ}$ journal and benefit from:}

- Convenient online submission

- Rigorous peer review

- Immediate publication on acceptance

- Open access: articles freely available online

- High visibility within the field

Retaining the copyright to your article

Submit your next manuscript at $\boldsymbol{\sim}$ springeropen.com 